\title{
The Effect of Orally Administering Forkhead Box P3 Recombinant Lactobacillus Plantarum on Regulatory T-cell Functionality in a Humanized Mouse Model for Rheumatoid Arthritis: A Research Protocol
}

Komalpreet K. Rehill, BSc Student [1]*, Inderpal S. Dosanjh, BSc Student [2], Ikjot K. Kahlon, BSc Student [1]

[1] Department of Biology, Irving K. Barber Faculty of Science, University of British Columbia, Kelowna, BC, Canada V1V 1 V7 Check for updates

[2] Department of Microbiology, Irving K. Barber Faculty of Science, University of British Columbia, Kelowna, BC, Canada V1V 1V7

*Corresponding Author: rehill.komal@gmail.com

\begin{abstract}
Introduction: Inflammation and joint stiffening are common symptoms of rheumatoid arthritis (RA), an autoimmune inflammatory disease. Previous treatments of RA have focused on decreasing symptomatic effects but have limited effects on disease progression. In RA, an influx of pro-inflammatory cytokines occurs at the synovium, which is the soft tissue surrounding the joints. The production of pro-inflammatory cytokines is controlled by regulatory T-cells, which have a deficit in function in RA patients. Regulatory T-cell development and function is regulated by the forkhead box P3 (FOXP3). The FOXP3 gene is a viable therapeutic target to restore regulatory T-cell functionality because FOXP3 is underexpressed in RA patients. Therefore, this study ventures to treat RA regulatory T-cell functionality by increasing FOXP3 gene expression through FOXP3 recombinant Lactobacillus plantarum bactofection. We hypothesize that bactofection will lead to a decrease in RA progression by restoring normal function in regulatory T-cells, thus decreasing inflammation.

Methods: We propose a study using severe combined immunodeficient mouse models engrafted with human RA synovium. The mice will be given either no treatment (control group) or a $2 \times 109$ CFU/g dose of recombinant Lactobacillus plantarum strain. The mice will be sacrificed after 0 days, 10 days, 20 days, and 30 days (control group and treatment groups respectively). Synovial tissue samples will be obtained from the hip joints. Through immunofluorescence and western blotting, the prevalence of FOXP3, regulatory T-cells and pro-inflammatory cytokines such as tumor necrosis factor-alpha, Interleukin-1 and Interleukin-6 will be compared between the control and treatment groups. For statistical analysis, a oneway MANOVA test, Levene's test, and a Shapiro-Wilk test will be performed using GraphPad Prism.

Results: As a result of bactofection, there will be an increase in FOXP3 and regulatory T-cells, resulting in a decrease of proinflammatory cytokines.

Discussion: Analysis of mice treated with recombinant Lactobacillus plantarum compared to mice with no treatment will set a correlation between FOXP3, regulatory T-cells, and pro-inflammatory cytokines prevalence and RA progression after treatment.

Conclusion: The findings of this study will provide evidence that bactofection is a viable treatment for RA, and may be more effective than conventional treatments.
\end{abstract}

Keywords: rheumatoid arthritis; forkhead box P3; regulatory T-cells; pro-inflammatory cytokines; Lactobacillus plantarum; bactofection

\section{Introduction}

Rheumatoid arthritis (RA) is a chronic inflammatory autoimmune disease, reportedly affecting approximately $0.5-1 \%$ of the adult population in developed nations [1]. Hallmarks of RA include pain and joint swelling due to inflammation, eventually leading to complete impairment of joint function [2-4]. Synovitis, inflammation in the synovium, is one of the initial symptoms of damage due to
RA [1,3]. The synovium is the soft tissue surrounding the joints [1]. Synovitis is caused by an overproduction of pro-inflammatory cytokines and other immune cells, including T-cells and B-cells, alongside angiogenesis [3,5]. Pro-inflammatory cytokines, such as tumor necrosis factoralpha (TNF- $\alpha$ ), Interleukin-1 (IL-1) and Interleukin-6 (IL-6) have particularly significant roles in promoting inflammation during RA [2]. 
UNDERGRADUATE RESEARCH IN NATURAL AND CLINICAL SCIENCE AND TECHNOLOGY (URNCST) JOURNAL Read more URNCST Journal articles and submit your own today at: $\underline{\text { htps://www.urncst.com }}$

Inflammation begins with activation of the innate immune response [3]. Antigen-presenting cells such as macrophages and dendritic cells, present antigens linked with RA to T-cells [3]. This allows $\mathrm{CD}^{+} \mathrm{T}$-cells to pass through the synovial membrane and secrete proinflammatory cytokines [3]. B-cells are also activated, thus producing cytokines and antibodies, as well as presenting antigens [3,6]. T-cell and B-cell activation triggers the release of a cascade of cytokines and chemokines to occur $[3,5,6]$. Eventually, degradation of cartilage occurs when cytokines TNF- $\alpha$, IL-1, and IL-6 activate synoviocytes. Synoviocyte activation results in the secretion of matrix metalloproteinases, causing degradation of the extracellular matrix $[3,5,6]$.

One of the key players associated with inflammation in the body are regulatory T-cells (Tregs). Tregs have an important role in regulating or suppressing cells in the immune system [7]. These cells help to prevent autoimmune diseases and manage the immune response to antigens [8]. Based on previous studies, it has been determined that Treg cells can influence tissue repair by entering the muscle and suppressing inflammation [9]. Tregs have been shown to have decreased function in RA patients. This Treg functionality deficit results in the overproduction of pro-inflammatory cytokines such TNF- $\alpha$, IL-1 and IL-6 [2,8]. Furthermore, Tregs expresses the transcription factor forkhead box protein (FOXP3) [8]. FOXP3 regulates the development and function of Treg cells, and therefore, has an important role in tissue repair and enforcing immune tolerance to autoimmune diseases. FOXP3 specifically oversees the development of Tregs in the thymus. Regular FOXP3 expression is required to ensure the proper development of Tregs in order to maintain their suppressive activity. The underexpression of FOXP3 in RA patients, is the reason for the decrease in function of Tregs in RAs patients [9].

Current common treatment options for RA are glucocorticoids, non-steroidal anti-inflammatory drugs (NSAIDs), and disease-modifying antirheumatic drugs (DMARDs) [5,6]. Although glucocorticoids are effective in reducing inflammation, they can be toxic at high dosages. As such, glucocorticoids are often used in combination with DMARDS [10]. NSAIDS and DMARDS serve to decrease pain and inflammation, allowing patients a higher quality of life; however, they are only symptomatic treatments, which must be continually administered [5]. In terms of slowing down RA disease progression, better therapies need to be developed, tested, and approved.

Bactofection is bacteria-mediated delivery of plasmidborne mammalian genes into target cells in order to induce target gene expression $[11,12]$. Previous studies involving cancer $[13,14]$ and cystic fibrosis $[15,16]$ have successfully employed bactofection to induce desired results. After the bacteria undergoes endocytosis and endosomal release, there are two different ways the transgene product is expressed in the target cell. Firstly, the transgene product can be produced and secreted directly by the bacteria. Only bacteria can use this method of transgene expression because they have the necessary components to produce mRNA, RNAi, and proteins, in contrast to other gene delivery systems [17]. Secondly, the transgene product can be expressed via host cell-mediated expression of a genetic cassette released by bacteria [17]. Genetic cassettes generally have no space for transcription signals due to their small size. Consequently, the cassettes require host integrons to provide a promoter to enable their gene expression [18]. Bacteria-mediated transgene expression has the capability to evade host cell defenses against exogenous DNA because the DNA is confined within the bacteria [17]. Through a previous study conducted by Birmingham et al. it was discovered that bacteria-mediated transgene expression can evade exogenous DNA host cell defences, due to the DNA being enclosed within the bacteria. Thus, bacteria-mediated transgene expression enabled long-term expression of the transgene [19]. As such, bactofection may provide longterm expression of FOXP3, providing a long-term treatment option for RA.

Lactobacillus species include various probiotic strains of Lactobacillus acidophilus, Lactobacillus reuteri, Lactobacillus rhamnosus, Lactobacillus johnsonii, and Lactobacillus plantarum. Lactobacillus plantarum (L. plantarum) is one of the most well studied species in terms of oral consumption [20]. Plasmid-borne Lactobacillus plantarum (L. plantarum) are facultatively anaerobic, gram-positive, non-spore-forming, rod shaped members of the family Lactobacillaceae. Furthermore, these microbes are a normal component of the gastrointestinal and vaginal flora in humans [21] and can survive ingestion because they can tolerate stomach acids. L. plantarum is classified as "generally recognized as safe" (GRAS) and as qualified presumption of safety (QPS) [20]. As such, L. plantarum is an ideal candidate for mediating gene delivery [21]. This study aims to explore feasibility of treating RA inflammation through FOXP3 recombinant $L$. plantarum bactofection, thus increasing FOXP3 gene expression and decreasing proinflammatory cytokine levels in severe combined immunodeficient mice engrafted with human RA synovium (SCID-HuRAg) mice models.

\section{Methods}

$\underline{\text { Animal Models }}$

We will be using eleven-week-old male and female SCID-HuRAgs as mice models. Eight mice will be used in each group, with fourteen groups in total (seven consisting of male mice and seven consisting of female mice). SCIDHuRAg mice have a defect in their V(D)J recombinase system. Consequently, the SCID mice are unable to reject xenogenic grafts due to their failure to develop mature $\mathrm{T}$ and B lymphocytes. The mice display histological characteristics closely similar to human RA. Since the transplanted tissue in this animal model originates from 
UNDERGRADUATE RESEARCH IN NATURAL AND CLINICAL SCIENCE AND TECHNOLOGY (URNCST) JOURNAL Read more URNCST Journal articles and submit your own today at: https://www.urncst.com

humans, it serves as an effective model for studies on the effect of treatment on RA pathogenesis [22]. The mice will be bred under specific pathogen-free conditions of the
Charles River Laboratories [23]. The experimental groups and subsequent investigative steps and tests are outlined in Figure 1.

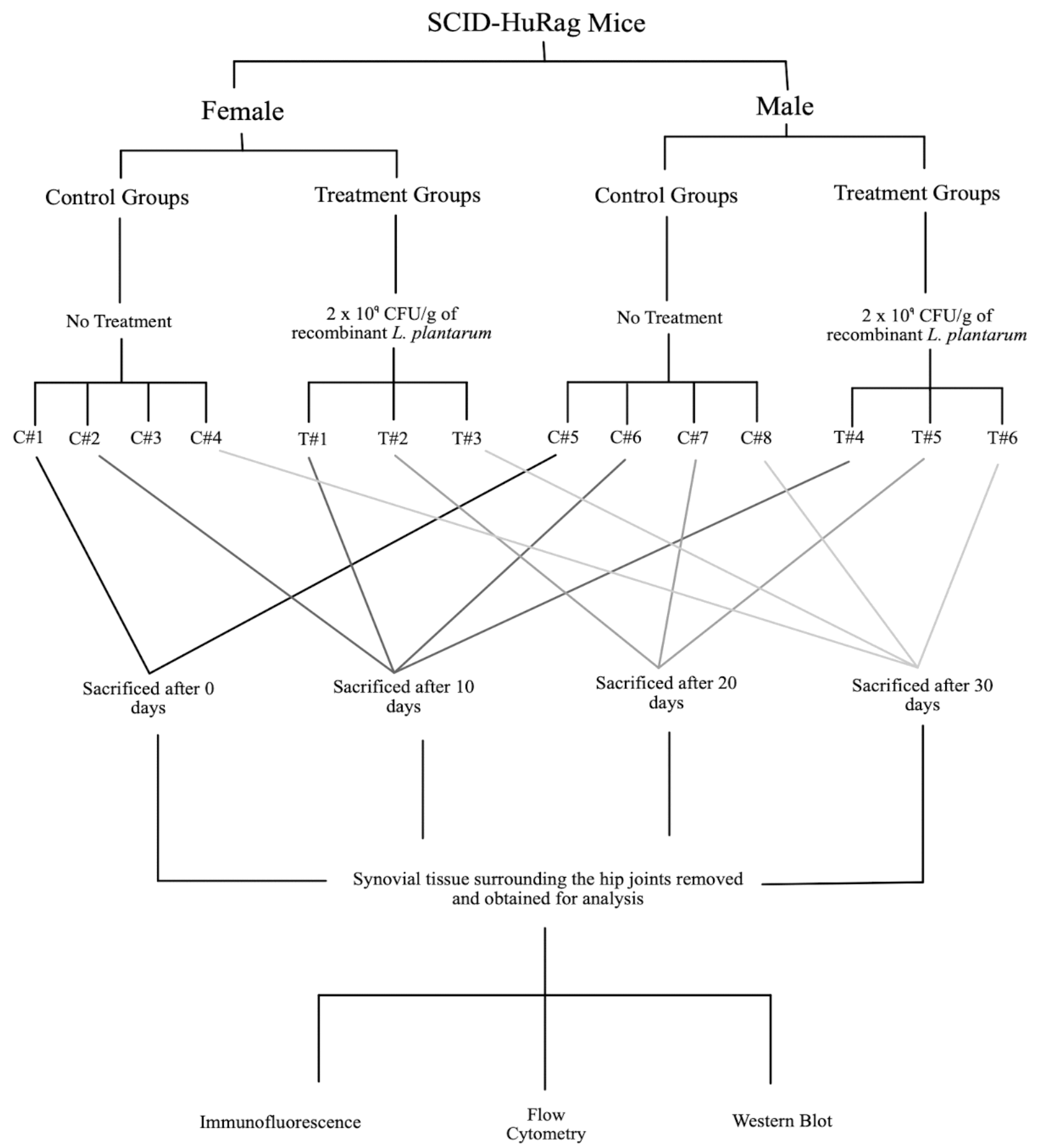

Figure 1. An experimental overview of the proposed study. $\mathrm{N}=8$ mice for each treatment and control, thus, a total of 112 mice will be used. SCID-HuRAg = Severe combined immunodeficient mouse model engrafted with human RA synovium; L. plantarum $=$ Lactobacillus plantarum, $\mathrm{CFU}=$ Colony Forming Unit, $\mathrm{C}=$ Control Group, $\mathrm{T}=$ Treatment Group. Figure made using Goodnotes 5. 
UNDERGRADUATE RESEARCH IN NATURAL AND CLINICAL SCIENCE AND TECHNOLOGY (URNCST) JOURNAL Read more URNCST Journal articles and submit your own today at: https://www.urncst.com

\section{$\underline{\text { Recombinant Bacteria }}$}

In this study, we aim to construct a recombinant FOXP3 lactobacillus species using the L. plantarum strain WCFS1 by in vivo recombination [24]. L. plantarum WCFS1 will be obtained from the appropriate manufacturer and will be maintained in De Man, Rogosa and Sharpe (MRS) media at $37^{\circ} \mathrm{C}$ in a $5 \% \mathrm{CO}_{2}$ atmosphere. The fragments (Forward Sequence: GGCACAATGTCTCC TCCAGAGA; Reverse Sequence: CAGATGAAGCC TTGGTCAGTGC) containing Foxp3 will be amplified using polymerase chain reaction (PCR) with a Q5 hot start high-fidelity DNA polymerase [24] and subcloned into modified pET-11d plasmids. These modified pET-11d plasmids will be used as templates for cloning into $L$. plantarum WCFS1 plasmid allowing amplification of the FOXP3 gene. The amplified fragments will be digested using Apal/Hpal and ligated using T4 DNA ligase into $L$. plantarum WCFS1 plasmid to obtain WCFS1-FOXP3 plasmids.

\section{Electroporation}

L. plantarum WCFS1 cells will be placed on ice prior to electroporation into competent $L$. plantarum WCFS1FOXP3. The WCFS1-FOXP3 plasmids will be combined with electrocompetent cells and incubated on ice for 5 minutes. Incubation will be followed by $1 \mathrm{kV} \mathrm{mm}^{-1}$ for $5 \mathrm{~ms}$ pulsing and immediate recovery with $1 \mathrm{~mL}$ MRS supplemented with $\mathrm{MgCl}_{2}$. These cells will be grown for 24 hours in a recovery media and plated on MRS agar with erythromycin in an anaerobic chamber [25,26].

\section{$\underline{\text { Administration/Bactofection }}$}

We will orally administer a dose of recombinant $L$. plantarum strain by gavage to all SCID-HuRAg mice treatment groups. Dosage concentration of $2 \times 109 \mathrm{CFU} / \mathrm{g}$ was determined using other studies as references $[27,28,29]$. The administration will be done at one time (zero time). L. plantarum will act as carriers in order to transport the plasmids and deliver the transgene into mice cells $[11,30]$.

\section{Tissue Samples}

Synovial tissue samples for immunostaining, western blot and flow cytometry will be isolated from the hip joints of the mice in both the control and treatment groups. There will be eight control groups and six treatment groups. The mice in the controls and treatment groups will be sacrificed through cervical dislocation and the synovial tissue surrounding their hip joints will be aspirated by syringe [31]. Control groups one and five will be sacrificed after zero days. Control groups two and six and treatment groups one and four will be sacrificed after 10 days. Control groups three and seven and treatment groups two and five will be sacrificed after 20 days. Finally, control groups four and eight and treatment groups three and six will be sacrificed after 30 days. The extracted tissue samples will be used to conduct secondary immunofluorescence, to extract proteins for western blotting and to produce synovial cell suspensions for flow cytometry. All the surgical procedures performed will be conducted under sterile conditions.

\section{Immunostaining}

Primary antibodies will be used to tag and bind FOXP3, TNF- $\alpha$, IL-6 and IL- 1 in each tissue sample, using separate slides for tagging each protein of interest. Secondary antibodies (anti-FOXP3 antibody, anti-IL-6 monoclonal antibody, anti-IL-1 antibody, and anti-TNF- $\alpha$ antibody) will be labeled with fluorescein isothiocyanate. Anti-FOXP3 antibodies will be used to tag FOXP3 and anti-IL-6 monoclonal antibodies will be used to tag IL-6. Anti-IL-1 antibodies will be used to tag IL-1 and anti-TNF$\alpha$ antibodies will be used to tag TNF- $\alpha$. Fluorescence microscopy will be conducted at an excitation wavelength of $495 \mathrm{~nm}$ and emission wavelength of $520 \mathrm{~nm}$ with an exposure time of $160 \mathrm{~ms}$ [32,33]. The resulting images will be analyzed to determine the prevalence of the proteins of interest in each sample.

\section{Protein Extraction}

The previously isolated synovial tissue samples will be frozen and then crushed in a cryotube using a sterile steel ball. A protein extraction will be performed and the extracted protein will be solubilized in $2 \%$ sodium dodecyl sulphate (SDS) for ten minutes, at $70^{\circ} \mathrm{C}$ by shaking [34]. These proteins will be used for western blotting.

\section{Western Blotting}

Western blotting for FOXP3, Treg, TNF- $\alpha$, IL-6 and IL-1 proteins will be used to validate immunofluorescence results as explained before. The previously extracted proteins will be used to prepare samples to be loaded onto a gel electrophorator. The electrophorator will run at $60 \mathrm{~V}$ for approximately one hour. The gel will then be moved to a transfer apparatus for 90 minutes where it will be sandwiched in between a polyvinylidene fluoride (PVDF) membrane. The membrane will then be blocked for one hour with 5\% skim milk in Tris Buffered Saline with Tween (TBST), and primary antibodies will then be added and incubated overnight. After incubation, the membrane will be washed three-times with TBST for five minutes, allowing for the unbound antibodies to be washed off, leaving the bound antibodies to the proteins of interest. The secondary antibodies will then be added and incubated for one hour. Once again, after incubation, the membrane will be washed three-times with TBST for five minutes. The enhanced chemiluminescence (ECL) mixture will then cover the top and bottom of the membrane. In a dark room, the blot will be visualized. The thickness of the bands will indicate the amount of each protein present in the sample [35]. This process will be conducted for all of the control and experimental samples separately. 
UNDERGRADUATE RESEARCH IN NATURAL AND CLINICAL SCIENCE AND TECHNOLOGY (URNCST) JOURNAL Read more URNCST Journal articles and submit your own today at: $\underline{\text { htps://www.urncst.com }}$

\section{Synovial Cell Suspension}

Using a scalpel, previously isolated synovial tissue samples will be minced into approximately $1 \mathrm{~mm}^{3}$ small fragments. At $37^{\circ} \mathrm{C}$, these small tissue fragments will then be enzymatically digested by hyaluronidase and collagenase for two hours. During enzymatic digestion of the tissues, the samples will also be continuously stirred [36]. At the end of the two hours, the cells will be centrifuged for ten minutes at room temperature. The supernatant will be discarded. The pellet will be resuspended in phosphate-buffered saline (PBS) and centrifuged again for ten minutes. Once again, the supernatant will be discarded and the pellet will now be suspended in a suitable volume of flow cytometry staining (FACS) buffer [37].

\section{Flow Cytometry}

Antibodies conjugated with fluorophores will be used to quantify FOXP3, TNF- $\alpha$, IL-6 and IL-1 levels. AntiFOXP3-fluoro-isothiocyanate will be used to tag FOXP3 and anti-TNF- $\alpha$-phycoerythrin will be used to tag TNF- $\alpha$. Anti-IL-6-allophycocyanin will be used to tag IL-6 and anti-IL-1-R-phycoerythrin will be used to tag IL-1. The samples will be incubated for an hour on ice, in the dark. Then, the samples will be washed and resuspended in a $2 \mathrm{ml}$ volume of FACS. The samples will then be centrifuged for five minutes. The supernatant will be discarded and the sample will then be resuspended in $2 \mathrm{ml}$ of FACS. Finally, the samples will proceed to be run on the flow cytometer and data will be recorded and analysed [38].

\section{Statistical Analysis}

The western blot and flow cytometry will be analyzed using ImageJ software. Results from flow cytometry will be used to determine statistical significance between groups one-way ANOVA (analysis of variance) tests will be performed. Before conducting the one-way ANOVA tests, a Shapiro-Wilk test will be used to test for normality. We will also test to eliminate univariate or multivariate outliers. These tests will be run using GraphPad Prism. Tukey's post-hoc test will be performed on the results to determine which specific dependent variables are different when compared to each other. p-values $<0.05$ will be considered significant.

\section{Results}

We will use SCID mouse models engrafted with human RA synovium. The mice will be given either no treatment (control groups) or a $2 \times 10^{9} \mathrm{CFU} / \mathrm{g}$ dose of recombinant Lactobacillus plantarum strain. Two male and female control groups will be sacrificed after 0 days. The remaining mice will be sacrificed after 10,20, and 30 days, each time point including both male and female control and treatment groups. If orally administering $2 \times 10^{9} \mathrm{CFU} / \mathrm{g}$ of recombinant $L$. plantarum strain is effective, it can be expected that there will be an increase in FOXP3, resulting in an increase in quantity and function of Treg cells.

Rehill et al. | URNCST Journal (2021): Volume 5, Issue 11 DOI Link: https://doi.org/10.26685/urnest.289
Restoration of Treg functionality is expected to subsequently lead to a reduction in pro-inflammatory cytokines (TNF- $\alpha$, IL-6 and IL-1). We expect that upon analyzing the immunofluorescence test results, there will be brighter areas representing FOXP3 and Treg cells and darker areas representing the pro-inflammatory cytokines in the experimental groups in contrast to the control group. This similar pattern of increase and decrease is expected to be consistent over the 10 day, 20 day, and 30 day experimental groups, with the largest difference seen between the 30 day treatment and control. These results will be confirmed using the western blot, in which the same pattern of increase in FOXP3 and Tregs and decrease in pro-inflammatory cytokines is expected to be seen between the experimental and control groups.

\section{Discussion}

The results will be used to compare mice treated with recombinant $L$. plantarum to mice with no treatment, and is expected to set a correlation between FOXP3, Treg, and pro-inflammatory cytokines prevalence and RA progression after treatment. Since RA is currently an incurable disease, better treatments than already available are needed.

When testing new therapeutic techniques using mouse models, it can be difficult to draw reliable conclusions due to immune system differences between humans and mice. However, using humanized models provides the ability to mimic the human immune system in mice [38]. As a result, humanized mice models are used to study a variety of human diseases such as HIV, Sepsis, Zika and Influenza [40-45].

L. plantarum was chosen as a model organism as it is a natural component of the gastrointestinal microbiome and for its acid-resistant properties that allow it to survive ingestion [21]. The mass production of the recombinant $L$. plantarum is expected to be economical due to the high reproductive rate of bacteria.

A possible limitation of this study is due to photobleaching in immunofluorescence, which would cause a decrease in fluorescence intensity and skew results [46]. To limit photobleaching, the immunofluorescence samples will be imaged promptly after staining and be kept in the dark when not in use, thereby limiting light exposure. When the fluorescent imaging will be conducted, the LED intensity will be set at an optimal level, thus also limiting photobleaching due to high levels of LED intensity. Another possible limitation of this study is due to only one concentration $\left(2 \times 10^{9} \mathrm{CFU} / \mathrm{g}\right)$ of recombinant L. plantarum being tested. It is possible that this dose is not effective, and a higher dose will be needed to see an effect. Further studies will be conducted to investigate dosage and how efficacy compares to standard pharmaceutical treatments of RA. 
UNDERGRADUATE RESEARCH IN NATURAL AND CLINICAL SCIENCE AND TECHNOLOGY (URNCST) JOURNAL Read more URNCST Journal articles and submit your own today at: https://www.urncst.com

\section{Conclusions}

Through proposing this experiment, our goal is to introduce L. plantarum as mediators of FOXP3 gene delivery while observing the effects on FOXP3, Treg and pro-inflammatory cytokine numbers in SCID-HuRAg mice, providing a possible novel therapy for RA patients. Through bactofection, we expect to provide a more effective therapy for patients with RA by increasing expression of FOXP3, ultimately resulting in a decrease of disease progression through restoration of Treg functionality. The findings of this study will provide evidence that bactofection is a viable treatment for RA. However, further investigations of the complex interaction of the L. plantarum bactofection and the immune system of the humanized mice is required. Further studies will also be conducted to investigate the ideal dosage for recombinant L. plantarum administration and to compare the efficacy of bactofection treatment with standard pharmaceutical treatments.

\section{List of Abbreviations Used}

ANOVA: analysis of variance

DMARDs: disease-modifying antirheumatic drugs

ECL: enhanced chemiluminescence

FOXP3: forkhead box P3

IL-1: interleukin-1

IL-6: interleukin-6

L. plantarum: Lactobacillus plantarum

MRS: De Man, Rogosa and Sharpe media

NSAIDs: non-steroidal anti-inflammatory drugs

PBS: phosphate-buffered saline

PCR: polymerase chain reaction

PVDF: polyvinylidene fluoride

RA: rheumatoid arthritis

SCID-HuRAg: severe combined immunodeficient mouse models engrafted with human RA synovium

SDS: sodium dodecyl sulphate

TBST: tris buffered saline with tween

TNF- $\alpha$ : tumor necrosis factor-alpha

Tregs: regulatory $\mathrm{T}$-cells

\section{Conflicts of Interest}

The authors declare that they have no conflict of interests.

\section{Ethics Approval and/or Participant Consent}

This article did not require ethics approval and/or participant consent as it was a research protocol, and thus, the experiment was not conducted. Ethics approval will be obtained from the University of British Columbia's Animal Care Committee prior to experimentation.

\section{Authors' Contributions}

KKR: made substantial contributions to the design of the study, contributed to study planning and drafting, critically revised the manuscript and gave final approval of the version to be published.

ISD: made substantial contributions to the design of the study, contributed to study planning and drafting, critically revised the manuscript and gave final approval of the version to be published.

IKK: contributed to the planning, design and drafting of the manuscript and gave final approval of the version to be published.

\section{Funding}

This study was not funded.

\section{References}

[1] Gabriel S. The epidemiology of rheumatoid arthritis. Rheumatic Disease Clinics of North America. 2001;27(2):269-281. https://doi.org/10.1016/s0889$\underline{857 x(05) 70201-5}$

[2] Choy E. Understanding the dynamics: Pathways involved in the pathogenesis of rheumatoid arthritis. Rheumatology. 2012;51(5):v3-v11. https://doi.org/ 10.1093/rheumatology/kes 113

[3] Heidari B. Rheumatoid arthritis: Early diagnosis and treatment outcomes. Caspian Journal of Internal Medicine. 2011;2(1):161-70. Available from: https://www.ncbi.nlm.nih.gov/pmc/articles/PMC37669 28/

[4] Bullock J, Rizvi S, Saleh A, Ahmed S, Do D, Ansari R et al. Rheumatoid arthritis: A brief overview of the treatment. Medical Principles and Practice. 2018;27(6):501-507. https://doi.org/10.1159/000493390

[5] Smolen J, Steiner G. Therapeutic strategies for rheumatoid arthritis. Nature Reviews Drug Discovery. 2003;2(6):473-488. https://doi.org/10.1038/nrd1109

[6] Smolen J, Aletaha D, Koeller M, Weisman M, Emery P. New therapies for treatment of rheumatoid arthritis. The Lancet. 2007;370(9602):1861-1874. https://doi.org/ 10.1016/S0140-6736(07)60784-3

[7] Li Y, Chen Y, Mao S, Kaundal R, Jing Z, Chen Q, et al. In situ conversion of defective Treg into SuperTreg cells to treat advanced IPEX-like disorders in mice. Nature Communications. 2020;11(1):2781. https://doi.org/10.1038/s41467-020-15836-2

[8] Campbell C, Rudensky A. Roles of regulatory T cells in tissue pathophysiology and metabolism. Cell Metabolism. 2020;31(1):18-25. https://doi.org/10.1016/ j.cmet.2019.09.010

[9] Al-Zifzaf D, El Bakry S, Mamdouh R, Shawarby L, Ghaffar A, Amer $\mathrm{H}$ et al. FoxP3+T regulatory cells in rheumatoid arthritis and the imbalance of the Treg/TH17 cytokine axis. The Egyptian Rheumatologist. 2015;37(1):7-15. https://doi.org/ 10.1016/j.ejr.2014.06.004 
UNDERGRADUATE RESEARCH IN NATURAL AND CLINICAL SCIENCE AND TECHNOLOGY (URNCST) JOURNAL

Read more URNCST Journal articles and submit your own today at: https://www.urncst.com

[10] Hua C, Buttgereit F, Combe B. Glucocorticoids in rheumatoid arthritis: Current status and future studies. Rheumatic and Musculoskeletal Diseases Open. 2020;6(1):e000536. https://doi.org/10.1136/ rmdopen-2017-000536

[11] Pilgrim S, Stritzker J, Schoen C, Kolb-Mäurer A, Geginat G, Loessner M et al. Bactofection of mammalian cells by Listeria monocytogenes: Improvement and mechanism of DNA delivery. Gene Therapy. 2003;10(24):2036-2045. https://doi.org/ 10.1038/sj.gt.3302105

[12] Johnson S, Ormsby M, McIntosh A, Tait S, Blyth K, Wall D. Increasing the bactofection capacity of a mammalian expression vector by removal of the $\mathrm{f} 1$ ori. Cancer Gene Therapy. 2018;26(7-8):183-194. https://doi.org/10.1038/s41417-018-0039-9

[13] Fu W, Chu L, Han X, Liu X, Ren D. Synergistic antitumoral effects of human telomerase reverse transcriptase-mediated dual-apoptosis-related gene vector delivered by orally attenuated Salmonella enterica Serovar Typhimurium in murine tumor models. The Journal of Gene Medicine. 2008;10(6):690-701. https://doi.org/10.1002/jgm.1191

[14] Nemunaitis J, Cunningham C, Senzer N, Kuhn J, Cramm J, Litz C, et al. Pilot trial of genetically modified, attenuated Salmonella expressing the $E$. coli cytosine deaminase gene in refractory cancer patients. Cancer Gene Therapy. 2003;10(10):737-744. https://doi.org/10.1038/sj.cgt.7700634

[15]Fajac I, Grosse S, Collombet J-M, Thevenot G, Goussard S, Danel C, et al. Recombinant Escherichia coli as a gene delivery vector into airway epithelial cells. Journal of Controlled Release. 2004;97(2):371381. https://doi.org/10.1016/j.jconrel.2004.03.025

[16] Krusch S, Domann E, Frings M, Zelmer A, Diener M, Chakraborty $\mathrm{T}$ et al. Listeria monocytogenes mediated CFTR transgene transfer to mammalian cells. The Journal of Gene Medicine. 2002;4(6):655-667. https://doi.org/10.1016/j.jconrel.2004.03.025

[17] Seow Y, Wood M. Biological gene delivery vehicles: Beyond viral vectors. Molecular Therapy. 2009;17(5):767-777. https://doi.org/10.1038/mt.2009.41

[18] Hall R. Gene cassettes. Encyclopedia of Genetics. 2001;771-774. https://doi.org/10.1006/rwgn.2001.1720

[19] Birmingham CL, Canadien V, Kaniuk NA, Steinberg BE, Higgins DE, Brumell JH. Listeriolysin O allows Listeria monocytogenes replication in macrophage vacuoles. Nature. 2008;451(7176):350-354. https://doi.org/10.1038/nature06479

[20] Behera SS, Ray RC, Zdolec N. Lactobacillus plantarum with functional properties: An approach to increase safety and shelf-life of fermented foods. BioMed Research International. 2018;2018:9361614. https://doi.org/10.1155/2018/9361614

Rehill et al. | URNCST Journal (2021): Volume 5, Issue 11 DOI Link: https://doi.org/10.26685/urncst.289
[21] Goldstein E, Tyrrell K, Citron D. Lactobacillus species: Taxonomic complexity and controversial susceptibilities. Clinical Infectious Diseases. 2015;60(2):S98-S107. https://doi.org/10.1093/cid/civ072

[22] Matsuno H, Yudoh K, Uzuki M, Kimura T. The SCIDHuRAg mouse as a model for rheumatoid arthritis. Modern Rheumatology. 2001;11(1):6-9. https://doi.org/ $10.3109 / \mathrm{s} 101650170036$

[23] Health reports for Charles river animal colonies in North America listed by species [Internet]. Criver.com. [cited 2021 Sep 7]. Available from:

https://www.criver.com/products-services/researchmodels-services/health-reports/north-america/northamerican-health-reports-species?region=3611

[24] Huang F, Spangler J, Huang A. In vivo cloning of up to $16 \mathrm{~kb}$ plasmids in $E$. coli is as simple as PCR. PLOS ONE. 2017;12(8):e0183974. https://doi.org/10.1371/ journal.pone.0183974

[25] Potter H. Transfection by electroporation. Current Protocols in Molecular Biology. 2003;9(1):9.3. https://doi.org/10.1002\%2F0471142727.mb0903s62

[26] Spangler JR, Caruana JC, Phillips DA, Walper SA. Broad range shuttle vector construction and promoter evaluation for the use of Lactobacillus plantarum WCFS1 as a microbial engineering platform. Synthetic Biology. 2019;4(1):ysz012. https://doi.org/10.1093/ synbio/ysz012

[27] Abboud M, Rizk R, AlAnouti F, Papandreou D, Haidar $\mathrm{S}$, Mahboub N. The health effects of vitamin D and probiotic co-supplementation: A systematic review of randomized controlled trials. Nutrients. 2020;13(1):111. https://doi.org/10.3390/nu13010111

[28] Lopez-Saucedo C, Bernal-Reynaga R, Zayas-Jahuey J, Galindo-Gomez S, Shibayama M, Garcia-Galvez C et al. CD40 ligand deficient C57BL/6 mouse is a potential surrogate model of human X-linked hyper IgM (X-HIGM) syndrome for characterizing immune responses against pathogens. BioMed Research International. 2015;2015:1-11. https://doi.org/10.1155/ 2015/679850

[29] Symonds E, Riedel C, O'Mahony D, Lapthorne S, O'Mahony L, Shanahan F. Involvement of T helper type 17 and regulatory $\mathrm{T}$ cell activity in Citrobacter rodentium invasion and inflammatory damage. Clinical \& Experimental Immunology. 2009;157(1):148-154. https://doi.org/10.1111/j.1365-2249.2009.03934.x

[30] Pálffy R, Gardlík R, Hodosy J, Behuliak M, Reško P, Radvánský $\mathbf{J}$ et al. Bacteria in gene therapy: Bactofection versus alternative gene therapy. Gene Therapy. 2005;13(2):101-105. https://doi.org/10.1038/ sj.gt. 3302635

[31] Zhao J, Ouyang Q, Hu Z, Huang Q, Wu J, Wang R et al. A protocol for the culture and isolation of murine synovial fibroblasts. Biomedical Reports. 2016;5(2):171-175. https://doi.org/10.3892/br.2016.708 
UNDERGRADUATE RESEARCH IN NATURAL AND CLINICAL SCIENCE AND TECHNOLOGY (URNCST) JOURNAL

Read more URNCST Journal articles and submit your own today at: https://www.urncst.com

[32] Sert M, Cakir Koc R, Budama Kilinc Y. Novel FitcLabeled Igy Antibody: Fluorescence imaging Toxoplasma gondii in vitro. Scientific Reports. 2017;7(1). https://doi.org/10.1038/s41598-017-00930-1

[33] Abuknesha R, Al-Mazeedi H, Price R. Reduction of the rate of fluorescence decay of FITC-and carboxyfluorescein-stained cells by anti-FITC antibodies. The Histochemical Journal. 1992;24(2):7377. https://doi.org/10.1007/BF01082442

[34] Ericsson C, Nistér M. Protein extraction from solid tissue. Methods in Molecular Biology. 2011;675:307312. https://doi.org/10.1007/978-1-59745-423-0_17

[35] Mahmood T, Yang P-C. Western blot: Technique, theory, and trouble shooting. North American Journal of Medical Sciences. 2012;4(9):429-34. https://doi.org/ 10.4103/1947-2714.100998

[36] Van Landuyt KB, Jones EA, McGonagle D, Luyten FP, Lories RJ. Flow cytometric characterization of freshly isolated and culture expanded human synovial cell populations in patients with chronic arthritis. Arthritis Research \& Therapy. 2010;12(1):R15. https://doi.org/10.1186/ar2916

[37] Flow cytometry sample preparation [Internet]. Bosterbio.com. [cited $2021 \mathrm{Sep}$ 7]. Available from: https://www.bosterbio.com/protocol-andtroubleshooting/flow-cytometry-sample-preparation

[38] Hawley TS, Hawley RG, editors. Flow Cytometry Protocols [Internet]. New York, NY: Humana Press; 2018 [cited $2021 \mathrm{Sep} 7]$. Available from: https://enquirebio.com/flow-cytometry

[39] Schinnerling K, Rosas C, Soto L, Thomas R, Aguillón JC. Humanized mouse models of rheumatoid arthritis for studies on immunopathogenesis and preclinical testing of cell-based therapies. Frontiers in Immunology. 2019;10:203. https://doi.org/10.3389/ fimmu.2019.00203

[40] Misharin AV, Haines GK 3rd, Rose S, Gierut AK, Hotchkiss RS, Perlman H. Development of a new humanized mouse model to study acute inflammatory arthritis. Journal of Translational Medicine.

2012;10(1):190. https://doi.org/10.1186/1479-5876-10190
[41] Skirecki T, Kawiak J, Machaj E, Pojda Z, Wasilewska $\mathrm{D}$, Czubak J, et al. Early severe impairment of hematopoietic stem and progenitor cells from the bone marrow caused by CLP sepsis and endotoxemia in a humanized mice model. Stem Cell Research \& Therapy. 2015;6(1):142. https://doi.org/10.1186/ s13287-015-0135-9

[42] Nolte T, Zadeh-Khorasani M, Safarov O, Rueff F, Gülberg V, Herbach N, et al. Oxazolone and ethanol induce colitis in non-obese diabetic-severe combined immunodeficiency interleukin-2R $\gamma$ (null) mice engrafted with human peripheral blood mononuclear cells: Mouse model of human UC. Clinical \& Experimental Immunology. 2013;172(2):349-62. https://doi.org/10.1111/cei.12057

[43] Willinger T, Rongvaux A, Takizawa H, Yancopoulos GD, Valenzuela DM, Murphy AJ, et al. Human IL3/GM-CSF knock-in mice support human alveolar macrophage development and human immune responses in the lung. Proceedings of the National Academy of Sciences of the United States of America. 2011;108(6):2390-5. https://doi.org/10.1073/pnas .1019682108

[44] Walsh NC, Kenney LL, Jangalwe S, Aryee K-E, Greiner DL, Brehm MA, et al. Humanized mouse models of clinical disease. Annual Review of Pathology. 2017;12(1):187-215. https://doi.org/10.1146/annurevpathol-052016-100332

[45] Yu CI, Becker C, Wang Y, Marches F, Helft J, Leboeuf M, et al. Human CD1c+ dendritic cells drive the differentiation of CD103+CD8+ mucosal effector $\mathrm{T}$ cells via the cytokine TGF- $\beta$. Immunity. 2013;38(4):818-30. https://doi.org/10.1016/j.immuni .2013 .03 .004

[46] Johnson G, Davidson R, McNamee K, Russell G, Goodwin D, Holborow E. Fading of immunofluorescence during microscopy: A study of the phenomenon and its remedy. Journal of Immunological Methods. 1982;55(2):231-242. https://doi.org/10.1016/0022-1759(82)90035-7

\section{Article Information}

Managing Editor: Jeremy Y. Ng

Peer Reviewers: Sonya Kouthouridis, Kumar Siddharth Singh

Article Dates: Received Jun 01 21; Accepted Sep 13 21; Published Nov 0221

\section{Citation}

Please cite this article as follows:

Rehill KK, Dosanjh IS, Kahlon IK. The effect of orally administering forkhead box P3 recombinant Lactobacillus Plantarum on regulatory T-cell functionality in a humanized mouse model for rheumatoid arthritis: A research protocol. URNCST Journal. 2021 Nov 02: 5(11). https://urncst.com/index.php/urncst/article/view/289

DOI Link: https://doi.org/10.26685/urncst.289 
UNDERGRADUATE RESEARCH IN NATURAL AND CLINICAL SCIENCE AND TECHNOLOGY (URNCST) JOURNAL

Read more URNCST Journal articles and submit your own today at: https://www.urncst.com

\section{Copyright}

(c) Komalpreet K. Rehill, Inderpal S. Dosanjh, Ikjot K. Kahlon. (2021). Published first in the Undergraduate Research in Natural and Clinical Science and Technology (URNCST) Journal. This is an open access article distributed under the terms of the Creative Commons Attribution License (https://creativecommons.org/licenses/by/4.0/), which permits unrestricted use, distribution, and reproduction in any medium, provided the original work, first published in the Underg raduate Research in Natural and Clinical Science and Technology (URNCST) Journal, is properly cited. The complete bibliographic information, a link to the original publication on http://www.urncst.com, as well as this copyright and license information must be included.

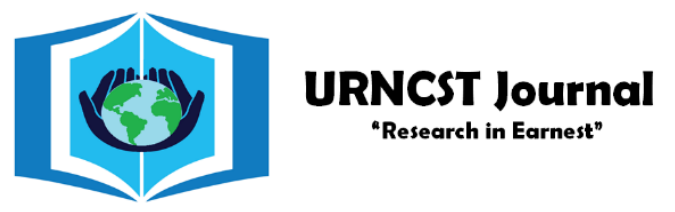

\section{Funded by the Government of Canada}

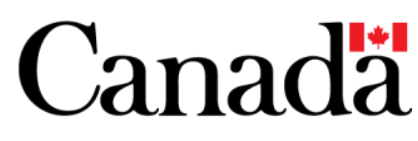

Do you research in earnest? Submit your next undergraduate research article to the URNCST Journal!

| Open Access | Peer-Reviewed | Rapid Turnaround Time | International | | Broad and Multidisciplinary | Indexed | Innovative | Social Media Promoted |

Pre-submission inquiries? Send us an email at info@ urncst.com | Facebook, Twitter and LinkedIn: @URNCST

Submit YOUR manuscript today at https://www.urncst.com! 